\title{
PENGARUH FAKTOR INTERNAL DAN EKSTERNAL PETANI TERHADAP PENCEGAHAN KEBAKARAN LAHAN GAMBUT
}

\author{
Sustainable agriculture effort to realize the implementation of the peat fire prevention peat fire
}

\author{
Robi Deslia Waldi ${ }^{1 *}$, Bambang Hero Saharjo ${ }^{2}$, Israr Albar ${ }^{3}$
}

(Diterima Mei 2019/Disetujui Juli 2019)

\begin{abstract}
Peat fire prevention activities conducted by farmers as a form of they role in realizing sustainable agriculture. Sustainable agriculture can be run as to maximizing internal factors such as age, formal education, income, land area, land status, distance of land location and exsternal factors such as interaction with instructor or instructor instructors, community leaders, involvement in farmer groups, information media, and government roles. Using SPSS 25 with validity in order test to test the level of relationship and validity, validity by looking at $r$ count $>r$ table which called then valid and if $r$ count $<r$ table then called invalid and reliability tests to know reliable, if the reliability coefficient is Alpha Cronbach is more than 0.70 (ri> 0.70) and should not be more than 0.90 (ri<0.9). Result of research shown that The Internal and external factors still have a relatively low level connection, because the facilities and infrastructures are not maximized to support sustainable agricultural development. Meanwhile internal factors that have a real relationship are age and formal education while external factors that have a real relationship are involvement in farmer groups, information media, and communication and the role of government.
\end{abstract}

Key words: exsternal factors, internal factors, peat fire prevention, sustainable agriculture

\section{PENDAHULUAN}

Pembangunan pertanian berkelanjutan (sustainable agriculture) merupakan salah satu bagian dari konsep pembangunan berkelanjutan (sustainable development) yang didasari oleh adanya peningkatan jumlah penduduk setiap tahunnya. Berdasarkan data dari Badan Pusat Statistik (2018) bahwa laju pertumbuhan penduduk menurut provinsi 2010 - 2017 sebesar $1.34 \%$ memiliki hubungan tehadap penurunan luas penggunaan lahan pertanian di Indonesia dari tahun 2013 - 2017 terjadi penurunan sebesar $5.404 \%$ data dari PusdatinKementan (2018). Adanya perubahan alih fungsi lahan pertanian tersebut menyebabkan lahan-lahan marginal menjadi pilihan untuk pemenuhan kebutuhan lahan pertanian, namun tetap dengan melakukan usaha-usaha perbaikan terlebih dahulu (Hardjowigeno dan Widiatmaka 2007).

Lahan marginal pada lahan basah di antara berupa lahan gambut, lahan sulfat masam, dan rawa pasang surut, sebaran lahan gambut tropika di Indonesia mencapai 14.95 juta hektare yang tersebar di tiga pulau besar (Sumatera, Kalimantan, dan Papua) dan luasan tersebut tidak termasuk lahan gambut di pulau lainnya (Ritung et al. 2011). Sekitar 30\% dari lahan gambut

\footnotetext{
${ }^{1}$ Program Studi Pengelolaan Sumberdaya Alam dan

Lingkungan, Sekolah Pascasarjana - IPB University

* Penulis korespondensi:

e-mail: robi_fahutan49@apps.ipb.ac.id

${ }^{2}$ Departemen Silvikultur Fakultas Kehutanan IPB University

${ }^{3}$ Balai Pengendalian Perubahan Iklim dan Kebakaran Hutan dan Lahan Wilayah Sumatera, KLHK
}

tersebut berpotensi untuk pengembangan pertanian. Lahan gambut terluas terletak di pulau Sumatera yakni 6.4 juta hektare, dengan $60 \%$ nya atau sekitar 3.8 juta hektare terletak di Provinsi Riau dari luas daratan 89 $150.15 \mathrm{~km}^{2}$. Luas daratan di Riau tersebut sebesar $56 \%$ merupakan ekosistem lahan gambut dan $44 \%$ berupa lahan mineral (Silalahi 2014). Pengembangan pertanian di lahan gambut pada kenyataannya menimbulkan kerusakan kualitas lahan gambut itu sendiri hal ini dikarenakan kurangnya implementasi kaidah-kaidah konservasi lahan gambut dan kurangnya pemahaman terhadap perilaku lahan rawa gambut sehingga penggunaan teknologi cenderung kurang tepat (Najiyati sri et al. 2005).

Pengelolaan lahan gambut yang tepat diperlukan dalam mendukung upaya pemanfaatan lahan gambut sebagai lahan pertanian berkelanjutan seperti kecermatan dan ketelitian dalam perencanaan dan penggunaan teknologi pengolahan lahan (Ratmini 2012). Hal yang paling mendasar dalam pengembangan lahan pertanian di lahan gambut yaitu pembukaan lahan tanpa bakar (PLTB). Namun pelaksanaan pembukaan lahan tanpa bakar dianggap masih belum maksimal, sehingga masih ditemukan adanya praktik-praktik pembukaan lahan dengan cara dibakar. Kebakaran lahan gambut memiliki kerusakan dan resiko yang tinggi dibandingkan dengan kebakaran lahan mineral. Kerusakan lahan gambut yang tinggi ini terjadi akibat ulah manusia yang memiliki harapan besar terhadap masih belum dimanfaatkannya lahan gambut disekitarnya untuk pertanian. Pemanfaatan lahan gambut ini dikarenakan berkurangnya lahan pertanian di lahan bukan gambut akibat adanya alih fungsi lahan. 
Penelitian ini bertujuan untuk menganalisis faktor internal dan eksternal yang mempengaruhi peran petani dalam pencegahan kebakaran lahan gambut sebagai upaya mewujdukan pertanian berkelanjutan di Desa Sungai Rawa dan Rawa Mekar Jaya Kecamatan Sungai Apit Kabupaten Siak Provinsi Riau.

\section{METODE PENELITIAN}

\section{Waktu dan Tempat Penelitian}

Penelitian dilaksanakan pada Bulan Agustus 2018 April 2019. Bertempat di dua desa yaitu Desa Sungai Rawa dan Rawa Mekar Jaya Kecamatan Sungai Apit Kabupaten Siak Provinsi Riau. Pemilihan kedua lokasi ini karena merupakan wilayah pembinaan dan pemberdayaan masyarakat dari Badan Restorasi Gambut (BRG) serta wilayah pelatihan dan penyuluhan yang dilakukan oleh IPB bekerjasama dengan UNESCO, sehingga peneliti mudah untuk mendalami faktor eksternal yang sudah diberikan kepada petani di lahan gambut.

\section{Pengambilan Data}

Penelitian ini menggunakan teknik pengambilan sampel dengan teknik purposive sampling secara non probability sampling dimana dasar penentuan sampel berdasarkan pertimbangan tertentu, yaitu petani pemilik maupun penggarap di lahan gambut di Desa Sungai Rawa dan Rawa Mekar Jaya Kecamatan Sungai Apit Kabupaten Siak Provinsi Riau. Penelitian ini menggunakan jumlah sampel sebanyak 30 orang responden dengan pertimbangan bahwa 30 orang responden ini merupakan informan yang memiliki informasi kritis terkait pertanian berkelanjutan di lahan gambut dan pernah mengikuti kegiatan pelatihan pembukaan lahan tanpa bakar (PLTB) yang diadakan oleh pemerintah, institusi pendidikan ataupun perusahan-perusahan di wilayah tersebut.

\section{Batasan Operasional}

Batasan operasional yang digunakan terdiri dari dua variabel yaitu variabel bebas (X) dan variabel tidak bebas (Y). Variabel bebas (X) terdiri dari faktor internal (umur, pendidikan formal, pendapatan, luas lahan, status lahan, jarak lokasi lahan) dan eksternal (interaksi dengan instruktur pelatih atau penyuluh, tokoh masyarakat, keterlibatan dalam kelompok tani, media informasi, dan peran pemerintah). Sementara, variabel tidak bebas (Y) terdiri dari sikap petani terhadap pengelolaan lahan tanpa bakar (Y1) dan tingkat peran petani dalam mewujudkan pertanian berkelanjutan dalam upaya pencegahan kebakaran lahan (Y2).

\section{Hipotesis Penelitian}

Hipotesis dalam penelitian ini menilai apakah terdapat hubungan yang positif antara faktor internal petani (X1) dan eksternal (X2) petani dengan peran petani dalam upaya pencegahan kebakaran lahan gambut (Y).

\section{Instrumentasi}

Instrumen-instrumen yang dilakukan dalam penelitian ini yaitu pengujian statistik berdasarkan validitas dan reliabilitasnya. Pengujian validitas tiap butir kuisioner dilakukan pada program SPSS 25 dengan menggunakan teknik korelasi product moment antara nilai tiap butir kuisioner dengan nilai total (jumlah tiap nilai kuisioner) (Sugiyono dan Wibowo 2002). Kriteria pengujian apabila $r$ hitung $>r$ tabel maka alat ukur tersebut dinyatakan valid, dan sebaliknya apabila $r$ hitung < $r$ tabel maka alat ukur tersebut adalah tidak valid. Sementara, Pengujian reliabilitas menggunakan uji Alfa Cronbach dilakukan untuk instrumen yang memiliki jawaban benar lebih dari satu (Adamson dan Prion 2013). Menurut Nunnally (dalam Streiner 2003) menyatakan bahwa instrumen dikatakan reliabel jika koefisien reliabilitas Alfa Cronbach lebih dari 0,70 (ri > 0,70) dan Streiner sendiri (2003) menyatakan bahwa koefisien reliabilitas Alfa Cronbach, tidak boleh lebih dari 0.90 (ri < 0.9).

\section{Pengumpulan Data}

Penelitian yang dilakukan ini terdiri dari data primer dan data sekunder. Data primer yang dikumpulkan dalam penelitian ini dilakukan dengan melakukan wawancara mendalam (indept interview) kepada 30 orang responden berumur produktif (15-64 tahun) yang bekerja sebagai petani. Wawancara ini dilakukan secara langsung dengan berpedoman pada pertanyaan terstruktur (quisioner) yang telah dipersiapkan terlebih dahulu dan observasi lapangan yang ditunjang oleh data sekunder sebagai upaya pengkajian lebih komprehensif dalam pengungkapan permasalahan yang diangkat dalam penelitian ini.

\section{Analisis Data}

Analisis data dalam penelitian ini dilakukan secara deskriptif kualitiatif dan kuantitatif berdasarkan data yang diperoleh. Analisis kuantitatif dilakukan apabila data yang diperoleh menyebar secara normal. Analisis secara statistik menggunakan koefesien korelasi Pearson product moment dan metode model regresi linear berganda dengan SPSS 25.

\section{Pengujian Hipotesis}

Berdasarkan hipotesis yang telah dikemukakan, maka bentuk pengujian hipotesis yang akan diuji dalam penelitian ini dalam melihat setiap hubungan antara variabel X1 dan X2 terhadap variabel Y1 dan Y2, pada data yang bersifat ordinal dianalisis menggunakan korelasi Spearman Rank, dengan menggunakan SPSS 25 (Silalahi 2012). 


\section{HASIL DAN PEMBAHASAN}

\section{Faktor Internal Petani Lahan Gambut}

Faktor internal merupakan faktor utama yang terdapat dalam diri seseorang yang mampu mengarahkan kekuatan berdasarkan tuntutan pribadi sesorang sehingga dapat mempengaruhi sebuah keputusan atau keinginan untuk mencapai tujuan tertentu. Faktor internal petani dilahan gambut dalam penelitian ini dapat dilihat pada Tabel 1 .

Petani di lahan gambut yang menjadi responden ini sebagin besar berumur produktif sebesar 96.67 persen yang berkisar diantara 15-49 sebanyak 25 orang (83.33 persen) dan di antara 50 - 65 tahun sebanyak 4 orang (13.33 persen) yang mampu melakukan pekerjaan dengan kekuatan fisik guna menghasilkan produktivitas yang baik sebagai upaya memenuhi kebutuhan sendiri ataupun orang lain. Hal ini dapat memberikan pengaruh yang besar untuk terus mengembangkan diri baik secara soft skill ataupun hard skill. Pekerjaan di sektor pertanian ini sangat ideal untuk dilakukan oleh sesorang yang berumur produktif sehingga dapat berkembang dengan cepat dalam mengadopsi inovasi-inovasi baru sesuai dengan kemajuan teknologi.

Sementara pada tingkat pendidikan formal yang dilakukan dalam penelitian ini didasari pada tiga kategori yaitu pendidikan setara SD, TK, PAUD dan tidak sekolah ( $<6$ tahun), SMP sederajat (6-9 tahun), dan SMA sederajat atau perguruan tinggi ( $>9$ tahun). Berdasarkan kategori tersebut bahwa pendidikan formal petani di lahan gambut sebanyak 14 orang (46.67 persen) berada pada kategori SMA sederajat atau perguruan tinggi (>9 tahun), hal ini dapat menjelaskan bahwa petani tersebut sudah mampu mengadopsi informasi yang baik dalam pengelolaan lahan gambut untuk pertanian. Selain itu, petani tersebut dapat mempengaruhi petani lainnya untuk ikut andil dalam membentuk kelompok tani untuk menjalin komunikasi yang intens sebagai bentuk partisipasi petani membangun pertanian yang berkelanjutan. Hal ini sesuai dengan pendapat dari Thamrin et al. (2012) bahwa pendidikan dapat mempengaruhi petani untuk menyerap dan menyebarkan informasi kepada sesama petani yang bermanfaat bagi peningkatan hasil produksi tanaman.

Pendapatan petani dalam penelitian ini mengelompokkan pada kategori Rp 1.5-2.5 juta/bulan sebanyak 13 petani (43.33 persen) dan lebih dari Rp 2.5 juta/bulan sebanyak 12 petani (40 persen). Hasil nilai rata-rata pendapatan petani sebesar 2.02 juta/bulan hal ini menunjukkan bahwa rata-rata tingkat pendapatan petani termasuk dalam kategori sedang. Nilai pendapatan rata-rata ini dapat menjelaskan bahwa sektor pertanian yang dikelola di lahan gambut dapat memberikan keuntungan tersendiri bagi petani sebagai upaya mensejahterakan perekonomian keluarganya.

Berdasarkan luas lahan garapan petani lebih banyak kurang dari 2 hektare sebanyak 29 petani (96.67 persen) dimana 16 petani tersebut memiliki luas lahan garapan diantara 0.5-2 hektare maka memiliki kemungkinan kecil petani untuk berperilaku membuka lahan dengan cara dibakar. Namun dengan lahan garapan diantara 0.5-2 hektare akan efektif dan efisien dalam pengelolaan pertanian di lahan gambut, hal ini sesuai dengan pendapat Sinaga (2015) bahwa Lahan yang terlalu luas tidak berarti dapat memberikan hasil produksi tinggi, tetapi lahan yang terlalu sempit juga tidak efisien dalam pengelolaan. Luas lahan garapan ini sebanding dengan status kepemilikan yang merupakan lahan milik pribadi sebanyak 18 petani ( 60 persen), hal ini menjelaskan bahwa petani di lahan gambut hanya memiliki lahan garapan yang kurang dari 2 hektare, yang seharusnya lebih luas karena lahan pertanian merupakan modal utama dalam pengembangan usaha pertanian.

Selain itu, faktor internal juga dipengaruhi oleh jarak lokasi lahan garapan yang merupakan jangkauan petani untuk menuju lokasi garapannya. Jarak lokasi lahan garapan petani ini hampir semuanya memiliki lahan garapan yang kurang dari 250 meter dari pemukiman

Tabel 1 Faktor internal petani di lahan gambut

\begin{tabular}{|c|c|c|c|c|}
\hline No & Faktor internal & Kategori & Jumlah (orang) & Persentase $(\%)$ \\
\hline \multirow[t]{3}{*}{1} & Umur & - $\quad$ Muda (15-49 tahun) & 25 & 83.33 \\
\hline & & - Sedang (50-65 tahun) & 4 & 13.33 \\
\hline & & - Tua (>65 tahun) & 1 & 3.33 \\
\hline \multirow[t]{3}{*}{2} & Pendidikan formal & $\begin{array}{l}\text { - Pendidikan > } 9 \text { tahun (SMA/sederajat dan } \\
\text { Perguruan Tinggi) }\end{array}$ & 14 & 46.67 \\
\hline & & - Pendidikan 6-9 tahun (SMP/sederajat) & 7 & 23.33 \\
\hline & & $\begin{array}{l}\text { - Pendidikan < } 6 \text { tahun (SD/sederajat, TK, PAUD } \\
\text { dan Tidak Sekolah) }\end{array}$ & 9 & 30 \\
\hline \multirow[t]{3}{*}{3} & Pendapatan & - $\quad>\operatorname{Rp} 2.5$ juta/bulan & 13 & 43.33 \\
\hline & & - $\quad \operatorname{Rp} 1.5-2.5$ juta/bulan & 12 & 40 \\
\hline & & - $\quad<$ Rp 1.5 juta/bulan & 5 & 16.67 \\
\hline \multirow[t]{3}{*}{4} & Luas lahan & - > 2 hektare & 1 & 3.33 \\
\hline & & - $0.5-2$ hektare & 16 & 53.33 \\
\hline & & - $<0.5$ hektare & 13 & 43.33 \\
\hline \multirow[t]{3}{*}{5} & Status lahan & - Milik pribadi & 18 & 60 \\
\hline & & - Milik kelompok atau bersama & 6 & 20 \\
\hline & & - Milik orang lain & 6 & 20 \\
\hline \multirow[t]{3}{*}{6} & Jarak lokasi lahan & - $\quad>500$ meter dari pemukiman & 4 & 13.33 \\
\hline & & - $\quad 250-500$ meter dari pemukiman & 4 & 13.33 \\
\hline & & - $\quad<250$ meter dari rumah pemukiman & 22 & 73.33 \\
\hline
\end{tabular}


sebanyak 73.33 persen. Lahan garapan yang dekat dengan pemukiman ini dilakukan sebagai salah satu pilihan untuk memudahkan dalam mengawasi secara intens dan bertransaksi secara langsung dengan pembeli atau tengkulak dalam jual beli hasil pertaniannya seperti nanas (Ananas comosus (L.) Merr.) yang dibudidayakan oleh petani. Selain itu, kemudahan dalam mencapai lahan garapan yang tidak perlu mengeluarkan modal dalam berkendera untuk menuju lahan pertaniannya.

\section{Faktor Eksternal Petani Lahan Gambut}

Faktor eksternal merupakan faktor lingkungan tempat seseorang bekerja yang dapat mempengaruhi dalam mengambil keputusan. Faktor-faktor yang mampu merubah perilaku petani lahan gambut dalam mengambil keputusan dalam penelitian ini adalah interaksi dengan instruktur pelatih atau penyuluh, dukungan tokoh masyarakat, keterlibatan dalam kelompok tani, media informasi dan komunikasi, dan peran pemerintah yang dapat dilihat pada Tabel 2 .

Peran penting yang dapat merubah perilaku petani yaitu kondisi lingkungannya, sehingga interaksi dan komunikasi petani dan lingkungannya menjadi sangat penting. Penyuluhan ini dapat disebut sebagai pendidikan non-formal yang bertujuan mengubah perilaku petani untuk mengembangkan potensi petani agar dapat memperbaiki diri dan lingkungannya. Interaksi petani dengan penyuluh yaitu tergolong sedang sebesar 80 persen. Petani menyebutkan bahwa kurang antusias dalam mengikuti penyuluhan karena dianggap hanya sebatas teori tanpa praktek, sedangkan yang ikut terlibat dalam kegiatan penyuluhan lebih banyak petani yang diajak secara langsung oleh penyuluh tersebut karena faktor kekerabatan. Interaksi petani dengan penyuluh tersebut sangat penting untuk membangkitkan kesadaran dan pemahaman petani terkait keberlangsungan pertaniannya yang mampu memperbaiki perilaku petani untuk berperan aktif dalam pelaksanaaan pencegahan kebakaran lahan. Sehingga tingkat kreatifitas dari penyuluh sangat dibutuhkan agar petani dapat terlibat dalam setiap kegiatan penyuluhan. Penyuluh harus mampu berperan sebagai fasilitator, komunikator, dan motivator bagi petani, yang pada akhirnya petani dpaat berperan sebagai leader dalam proses pencegahan kebakaran lahan dan pengelolaan pertanian berkelanjutan di lahan gambut.

Tokoh masyarakat memiliki peranan tersendiri dalam memberikan pengaruh kepada petani di lahan gambut untuk berperilaku sesuai dengan nilai dan norma yang berlaku. Nilai dan norma ini masih banyak dipegang teguh oleh petani di daerah-daerah perkampungan yang belum mengalami akulturasi di daerah tersebut. Dukungan tokoh masyarakat tergolong tinggi sebesar 73.33 persen yang mengatakan bahwa sangat berperan penting bagi petani. Sementara dukungan pemerintah yang memiliki peran dalam kebijakan tergolong sedang sebesar 40 persen dan tinggi sebesar 60 persen. Namun yang paling tinggi dukungannya yaitu kelompok tani yang tergolong sedang sebesar 60 persen dan tinggi sebesar 40 persen. Hal ini dapat menjelaskan bahwa keberadaaan kelompok tani sesuai dengan kebutuhan karena banyaknya permasalahan-permasalahan atau kendalakendala dalam pertanian di lahan gambut yang dapat ditemukan solusinya.

Selain itu, media informasi dan komunikasi sangat mempengaruhi faktor eksternal, hal ini dpaat dilihat bahwa petani tergolong sedang sebesar 46.67 persen dan tinggi sebesar 36.67 persen. Hal ini dapat menjelaskan bahwa media informasi dan komunikasi bagi petani sangat berrmanfaat dalam menjawab permasalahanpermasalahan yang muncul dalam pengelolaan lahan gambut untuk pertanian yang tidak dapat diselesaikan dalam kelompok tani ataupun tokoh masyarakat. Selain itu, media informasi ini dapat menjadi sarana bagi petani untuk terus meng-upgrade pengetahuannya untuk terus berinovasi dalam meningkatkan produksi.

\section{Pengaruh Faktor Internal dan Eksternal Terhadap Pencegahan Kebakaran Lahan Gambut}

Petani sebagai stakeholder terdepan dalam pencegahan kebakaran lahan gambut di tingkat tapak memiliki peranan yang sangat besar untuk mengawasi dan melaporkan setiap kejadian kebakaran yang terjadi. Petani sendiri merupakan pelaku utama dalam pembangunan pertanian di Indonesia yang melakukan pengolahan lahan untuk digarap. Oleh karena itu, petani sangat diperlukan perannya dalam pengelolaan lahan

Tabel 2 Faktor eksternal petani di lahan gambut

\begin{tabular}{|c|c|c|c|c|}
\hline No & Faktor eksternal & Kategori & Jumlah (orang) & Persentase $(\%)$ \\
\hline 1 & $\begin{array}{l}\text { Interaksi dengan instruktur pelatih atau } \\
\text { penyuluh }\end{array}$ & $\begin{array}{ll}\text { - } & \text { Tinggi }(>10) \\
\text { - } & \text { Sedang }(6-10) \\
\text { - } & \text { Rendah }(1>6)\end{array}$ & $\begin{array}{c}4 \\
24 \\
2\end{array}$ & $\begin{array}{l}13.33 \\
80 \\
2.67\end{array}$ \\
\hline 2 & Dukungan tokoh masyarakat & $\begin{array}{ll}\text { - } & \text { Tinggi }(>10) \\
\text { - } & \text { Sedang }(6-10) \\
\text { - } & \text { Rendah }(>6)\end{array}$ & $\begin{array}{c}22 \\
5 \\
3\end{array}$ & $\begin{array}{c}73.33 \\
16.67 \\
10\end{array}$ \\
\hline 3 & Keterlibatan dalam kelompok tani & $\begin{array}{ll}\text { - } & \text { Tinggi }(>10) \\
\text { - } & \text { Sedang }(6-10) \\
\text { - } & \text { Rendah }(>6)\end{array}$ & $\begin{array}{c}12 \\
18 \\
0\end{array}$ & $\begin{array}{c}40 \\
60 \\
0\end{array}$ \\
\hline 4 & Media informasi dan komunikasi & $\begin{array}{ll}\text { - } & \text { Tinggi }(>10) \\
\text { - } & \text { Sedang }(6-10) \\
\text { - } & \text { Rendah }(>6)\end{array}$ & $\begin{array}{c}11 \\
14 \\
5\end{array}$ & $\begin{array}{l}36.67 \\
46.67 \\
16.67\end{array}$ \\
\hline 5 & Peran pemerintah & $\begin{array}{ll}\text { - } & \text { Tinggi }(>10) \\
\text { - } & \text { Sedang }(6-10) \\
\text { - } & \text { Rendah }(>10)\end{array}$ & $\begin{array}{c}18 \\
12 \\
0\end{array}$ & $\begin{array}{c}60 \\
40 \\
0\end{array}$ \\
\hline
\end{tabular}


tanpa bakar sebagai salah satu upaya pencegahan kebakaran lahan gambut. Peran petani disini lebih diarahkan pada pengolahan lahan untuk lahan pertaniannya tanpa dilakukan dengan cara dibakar sebagai wujud mengedepankan aspek keberlanjutan pada lahan gambut itu sendiri. Sehingga pertanian di lahan gambut ini dapat membawa manfaat secara ekologi, ekonomi dan sosial dalam pelaksanannya. Faktor-faktor ini diuji secara statistik dengan menguji tingkat kereliabilitasan dari 13 kategori yang dipertanyakan dengan hasil 0.704, maka dapat dikatakan akurat atau tepat.

Faktor-faktor yang berhubungan dengan sikap petani terhadap pengelolaan lahan tanpa bakar dianalisis menggunakan uji korelasi Rank Spearman bahwa faktor internal memiliki hubungan yang nyata terhadap sikap petani dibandingkan faktor ekstrenal yang memiliki hubungan sangat nyata terhadap peran petani (Tabel 3). Faktor internal yang memiliki hubungan nyata yaitu umur dan pendidikan formal. Umur berhubungan sangat nyata terhadap sikap dan peran petani dalam pencegahan kebakaran lahan gambut, hal ini menjelaskan bahwa umur sangat berpengaruh terhadap perubahan perilaku petani yang mampu menerapkan pertanian secara efektif dan efesien. Sementara pendidikan formal memiliki hubungan nyata hanya terhadap sikap petani, hal ini karen pendidikan dapat mempengaruhi pola pikir dan pandangan untuk memberi respon atas apa yang diperolahnya.

Faktor-faktor eksternal yang memiliki hubungan sangat nyata terhadap peran petani dalam upaya pencegahan kebakaran lahan gambut yaitu keterlibatan dalam kelompok tani. Hal ini menjelaskan bahwa keterlibatan dalam kelompok tani sangat besar pengaruhnya karena kesamaan visi dan misi dalam mengembangkan potensi pertanian uyang menghasilkan produktivitas hasil yang tinggi. Faktor eksternal yang berhubungan nyata terhadap peran petani yang lainnya yaitu media informasi dan komunikasi dan peran pemerintah. Hal ini menjelaskan bahwa media informasi dan peran pemerintah sangat membantu dalam pengembangan pertanian namun belum banyak memberikan dampak yang besar terhadap produktivitas hasilnya.

Sementara faktor internal dan eksternal yang belum memberikan hubungan yang nyata yaitu status lahan dan interaksi petani kepada pelatih atau penyuluh. Hal ini menjelaskan bahwa perilaku petani tidak terlalu dipengaruhi oleh status lahan yang digarapnya dan belum sepenuhnya memiliki interaksi yang baik terhadap pelatih atau penyuluh. Petani beralasan bahwa dengan belum maksimalnya interaksi petani atau penyuluhpun petani masih dapat melakukan penggrapan lahan meskipun masih keterbatasan alat (cangkul dan arit). Petani lebih mengharapkan pemberian sarana dan prasarana dibandingkan teori-teori yang diberikan oleh pelatih atau penyuluh.

Tabel 3 Hubungan faktor eksternal dan internal petani terhadap sikap dan peran petani dalam upaya pencegahan kebakaran lahan

\begin{tabular}{|c|c|c|c|}
\hline Variabel/Kategori & & Sikap Petani & Peran Petani \\
\hline \multirow[t]{2}{*}{ Umur } & Koefesien Korelasi & $0.532 * *$ & $0.505^{* *}$ \\
\hline & $\mathrm{P}$ & 0.002 & 0.004 \\
\hline \multirow[t]{2}{*}{ Pendidikan formal } & Koefesien Korelasi & $0.402 *$ & 0.292 \\
\hline & $\mathrm{P}$ & 0.028 & 0.118 \\
\hline \multirow[t]{2}{*}{ Pendapatan } & Koefesien Korelasi & 0.365 & 0.297 \\
\hline & $\mathrm{P}$ & 0.047 & 0.110 \\
\hline \multirow[t]{2}{*}{ Luas Lahan } & Koefesien Korelasi & 0.186 & 0.026 \\
\hline & $\mathrm{P}$ & 0.326 & 0.892 \\
\hline \multirow[t]{2}{*}{ Status Lahan } & Koefesien Korelasi & 0.007 & -0.118 \\
\hline & $\mathrm{P}$ & 0.973 & 0.535 \\
\hline \multirow{2}{*}{ Jarak Lokasi Lahan } & Koefesien Korelasi & 0.177 & 0.207 \\
\hline & $\mathrm{P}$ & 0.305 & 0.273 \\
\hline \multirow[t]{2}{*}{ Faktor Internal } & Koefesien Korelasi & $0.389 *$ & 0.242 \\
\hline & $\mathrm{P}$ & 0.033 & 0.198 \\
\hline \multirow{2}{*}{$\begin{array}{l}\text { Interaksi petani dengan pelatih atau } \\
\text { penyuluh }\end{array}$} & Koefesien Korelasi & -0.215 & -0.053 \\
\hline & $\mathrm{P}$ & 0.255 & 0.782 \\
\hline \multirow{2}{*}{ Dukungan Tokoh Masyarakat } & Koefesien Korelasi & 0.045 & 0.095 \\
\hline & $\mathrm{P}$ & 0.813 & 0.618 \\
\hline \multirow[t]{2}{*}{ Keterlibatan dalam kelompok Tani } & Koefesien Korelasi & 0.202 & $0.483 * *$ \\
\hline & $\mathrm{P}$ & 0.285 & 0.007 \\
\hline \multirow[t]{2}{*}{ Media Informasi dan Komunikasi } & Koefesien Korelasi & 0.268 & $0.449^{*}$ \\
\hline & $\mathrm{P}$ & 0.155 & 0.013 \\
\hline \multirow[t]{2}{*}{ Peran Pemerintah } & Koefesien Korelasi & 0.214 & $0.431 *$ \\
\hline & $\mathrm{P}$ & 0.255 & 0.018 \\
\hline \multirow[t]{2}{*}{ Faktor Eksternal } & Koefesien Korelasi & 0.251 & $0.545^{* *}$ \\
\hline & $\mathrm{P}$ & 0.180 & 0.002 \\
\hline
\end{tabular}

Keterangan:

$\mathrm{n}=30$ orang; $\mathrm{P}=$ peluang kesalahan (galat)

* Berhubungan sangat nyata pad $\alpha 0.05$

** Berhubungan sangat nyata pad $\alpha 0.01$ 


\section{SIMPULAN DAN SARAN}

\section{Simpulan}

Faktor Internal berhubungan nyata terhadap sikap petani, sedangkan faktor eksternal berhubungan nyata terhadap peran petani. Faktor-faktor ini secara keseluruhan dapat merubah perilaku dan tindakan petani dalam melakukan pengelolaan lahan tanpa bakar sebagai upaya pencegahan kebakaran lahan gambut. Upaya meningkatkan faktor internal dan eksternal terhadap pencegahan kebakaran lahan gambut yakni dengan memasukan faktor dukungan teknologi pengolahan lahan sehingga dapat meningkatkan produktivitas pertanian dapat ditingkatkan.

\section{Saran}

Peningkatan perubahan perilaku pada petani perlu didorong oleh semua stakeholder baik dari kelompok tani, tokoh masyarakat, penyuluh, dan pemerintah. Hal ini dilakukan untuk meningkatkan partisipasi keikutsertaan petani di lahan gambut dalam kegiatan pelatihan, penyuluhan, dan ikut terlibat dalam melaporkan kejadian kebakaran lahan gambut. Selain itu, pelatihan yang diberikan diharapkan sesuai dengan yang dibutuhkan seperti pelatihan penggunaan teknologi dalam mengolah lahan, pelatihan peningkatan hasil produksi dan yang paling penting yaitu membantu membuka pasar agar hasil yang sudah di panen dapat langsung terjual.

\section{DAFTAR PUSTAKA}

Adamson K, Prion S. 2013. Reliability: Measuring internal consistency using Cronbach's $\alpha$. Clinical simulation in Nursing. 9(5):179-180.

[BPS] Badan Pusat Statistik. 2018. Statistik Indonesia 2018. Jakarta (ID): CV. Dharmaputra.
Hardjowigeno Sarwono, Widiatmaka. 2007. Evaluasi Kesesuaian Lahan dan Perencanaan Tata Guna Lahan. Yogyakarta (ID): UGM Press.

Najiyati S, Muslihat L, Suryadiputra INN, 2005. Panduan Pengelolaan Lahan Gambut untuk Pertanian Berkelanjutan. Bogor (ID): Wetlands International- Indonesia Programme.

Ratmini NPS. 2012. Karakteristik dan pengelolaan lahan gambut untuk pengembangan pertanian. Jurnal Lahan Suboptimal. Vol. 1(2): 197-206.

Ritung S, Wahyunto K. Nugroho, Sukarman, Hikmatullah, Suparto, dan C Tafakresnanto. 2011. Peta Lahan Gambut Indonesia, skala 1:250.000. Balai Besar Penelitian dan Pengembangan Sumberdaya Lahan Pertanian, Kementerian Pertanian.

Silalahi D. 2014. Policy dan Legalitas: RTRW, Hak Tanah, Perijinan dan Kelembagaan, Seminar Nasional Solusi Tuntas "Riau Bebas Asap", Pekanbaru (28-29 April, 2014).

Silalahi U. 2012. Metode Penelitian Sosial. Bandung (ID): Reflika Aditama.

Sinaga AH. 2015. Optimasi pengaruh faktor-faktor produksi usaha tani padi sawah. Jurnal Darma Agung. 1:26-29.

Streiner DL. 2003. Starting at the beginning: an introduction to coefficient alpha and internal consistency. Journal of Personality Assessment. 80 (1): 99-103.

Sugiyono dan Eri W. 2002. Statistik Untuk Penelitian Dan Aplikasinya Dengan SPSS 10,0 For Windows. Bandung (ID): Alfabeta.

[Pusdatin-Kementan] Pusat Data dan Sistem Informasi Kementerian Pertanian Republik Indonesia. Statistik Pertanian 2018. Jakarta (ID): Pusat Data dan Sistem Informasi Kementerian Pertanian Republik Indonesia.

Thamrin M, Herman S, dan Hanafi F. 2012. Pengaruh faktor sosial ekonomi terhadap pendapatan petani pinang. Agriu. 17 (2): 134-144. 